\title{
Problems of Cotton Farmers in Haryana
}

\author{
Reeta Devi Yadav* and Rita Goel \\ Department of Extension Education and Communication Management, I.C. College of Home \\ Science, CCSHAU, Hisar, Haryana, India \\ *Corresponding author
}

\begin{tabular}{|l|}
\hline K e y w o r d s \\
$\begin{array}{l}\text { Cotton cultivation, } \\
\text { Farmer's problem, } \\
\text { Seeds, Haryana }\end{array}$ \\
\hline Article Info \\
\hline $\begin{array}{l}\text { Accepted: } \\
\text { 18 February } 2019 \\
\text { Available Online: } \\
\text { 10 March } 2019\end{array}$ \\
\hline
\end{tabular}

\section{A B S T R A C T}

Cotton the "white gold" is premier industrial crop of major cotton growing countries like China, India, United States of America, Pakistan, Brazil, Uzbekistan, Egypt, Argentina, Australia and Turkey which accounts for nearly 85 per cent of the total global production. Apart from the increasing production of synthetic fibre, cotton has maintained its reputation as "king of the fibre crops". It is world's most important textile fibre and oil seed crop. The present study was conducted in Sirsa and Fatehabad district of Haryana state, purposively in the year 2015-16. Two blocks viz. Nathusari Chopta and Sirsa from Sirsa district and Bhuna and Bhattukalan from Fatehabad district were selected purposively. From each block one village was selected randomly and fifty farm families from each village were selected, thus making 200 families and total 400 respondents (husband and wife from each family). Interview schedule was used and data were collected personally, frequency and percentage were used to interpretation and analysis. Data regarding problems faced by respondents in cotton cultivation were climatic, seeds, fertilizer, irrigation, plant protection, shortage of labour and marketing. From climatic problems, unexpected rain (98.0\%) followed by outbreak of pests/diseases $(94.0 \%)$, regarding problem of seed majority of respondents had faced the problem of adulterated seed $(93.0 \%)$ and high cost of seed $(83.5 \%)$, while non-availability of seeds reported by 30.0 per cent of the respondents. High cost of fertilizer as their major problem $(99.0 \%)$, high cost of pesticides and chemicals $(99.0 \%)$, adulteration $(82.0 \%)$, high cost of labour wages (77.5\%) majority had reported very less MSP (98.0\%) followed by low rate of return $(96.0 \%)$ respectively.

\section{Introduction}

Cotton the "white gold" is premier industrial crop of major cotton growing countries like China, India, United States of America, Pakistan, Brazil, Uzbekistan, Egypt, Argentina, Australia and Turkey which accounts for nearly 85 per cent of the total global production. Apart from the increasing production of synthetic fibre, cotton has maintained its reputation as "king of the fibre crops" (Shiv Kumar, 2007). It is world's most important textile fibre and oil seed crop. The share of Haryana in area and production of cotton in India was 6.14 lakh hectares and 24.00 lakh bales respectively during the year 2010-13. India also exported 4.58 lakh tones of cotton worth Rs.2866 crore in 2011-12 
(Anonymous, 2012). In 2011-12, it was cultivated on about 12.19 million hectares producing 35.3 million bales. In last ten years, cotton acreage has been growing at an average annual rate of around 3.00 per cent. However, the average cotton yield in India is only 0.49 tons per hectares compared to world average of 0.73 tons per hectare (International Cotton Advisory Committee, 2010). In the subsequent year the cotton area and production shrunken to 11.77 million hectare and 34 million bales respectively (Anonymous, 2013). The low yields of cotton in India are attributed to inadequate input usage, rain fed cultivation, untimely operations on field and inefficient crop production technologies (Majumdar, 2012). The low yields persistent in Indian cotton production are also attributed to the lack of disease resistant and high yielding varieties. Another factor affecting the yield is rainfall pattern in India. About 65.00 per cent of the cotton acreage in India is dependent on rain; the annual variation in monsoon rainfall plays an important role in production and yield for any particular year (Aggarwal, et al., 2008). Thus, keeping in view the low production and productivity of cotton crop, the study was carried out with the objective of problems faced by cotton farmers in Haryana.

\section{Materials and Methods}

Present study was conducted in Sirsa and Fatehabad district of Haryana state, purposively in the year 2015-16. Two blocks viz. Nathusari Chopta and Sirsa from Sirsa district and Bhuna and Bhattukalan from Fatehabad district were selected purposively. From each block one village was selected randomly and fifty farm families from each village were selected, thus making 200 families and total 400. Interview schedule was used and data were collected personally, frequency and percentage were used to interpretation and analysis.

\section{Results and Discussion}

\section{Cotton varieties and their production potential}

Data presented in Table 1 revealed the information regarding cotton varieties grown and the production potential of the varieties as perceived by respondents. Cent percent respondents had grown $B t$ cotton, while 12.5 per cent had also grown Desi cotton. Regarding production potential, majority of the respondents $(72.50 \%)$ had perceived yield 7.5 to 11 quintal/acres, followed by 19.5 per cent had perceived 4 to 7 quintal/acre yield and 8.0 per cent had perceived 11.5 to 15 quintal/acre yield for $B t$ cotton. The production potential for Desi cotton 11.0 per cent had perceived 3.5 t 5 quintal/acre yield and only 1.5 per cent had perceived 5.5 t 8 quintal/acre yield.

Problems of farmers were studied in terms of climatic, seeds, fertilizer, irrigation, plant protection, shortage of labour and marketing in cotton cultivation and presented in Table 2 as follows; Climatic problems as perceived by respondents, majority had reported unexpected rain $(98.0 \%)$ followed by outbreak of pests/diseases (94.0\%). Regarding problem of seed majority of respondents had faced the problem of adulterated seed $(93.0 \%)$ and high cost of seed (83.5\%), while nonavailability of seeds reported by 30.0 per cent of the respondents. Table 2 further elucidated information regarding fertilizer majority of the respondents had reported, high cost of fertilizer as their major problem (99.0\%) followed by lack of knowledge about correct dose $(31.0 \%)$, while 8.5 per cent had reported non-availability of fertilizer as their problem. Regarding problem of irrigation, water shortage in canal was reported by 62.5 per cent of the respondents. Data presented in Table 2 pinpointed that high cost of pesticides and chemicals $(99.0 \%)$, adulteration $(82.0 \%)$, 
lack of knowledge about correct dose (54.5\%) and non- availability of pesticides (38.0\%) were the problems of plant protection as perceived by respondents. Further it was evident from the Table 2 that high cost of labour wages (77.5\%) and shortage of labour
(55.5\%) were also the problem in cotton cultivation. Problems faced by respondents regarding marketing of cotton majority had reported very less MSP (98.0\%) followed by low rate of return $(96.0 \%)$ and heavy price fluctuation $(32.5 \%)$ respectively.

Table. 1 Varieties and their production potential of cotton perceived by respondents $n=400$

\begin{tabular}{|l|l|l|l|}
\hline S.N. & Varieties & $\boldsymbol{f}$ & $\mathbf{( \% )}$ \\
\hline $\mathbf{1 .}$ & $\mathbf{B t}$ & 400 & 100.00 \\
\hline & Yield/acre (in quintals) & & \\
\hline & 4 to 7 & 78 & 19.50 \\
\hline & 7.5 to 11 & 290 & 72.50 \\
\hline & 11.5 to 15 & 32 & 8.00 \\
\hline 2. & Desi & 50 & 12.50 \\
\hline & Yield/acre (in quintals) & & \\
\hline & 3.5 to 5 & 44 & 11.00 \\
\hline & 5.5 to 8 & 6 & 1.50 \\
\hline
\end{tabular}

Table. 2 Problems in cotton cultivation $n=400$

\begin{tabular}{|c|c|c|c|}
\hline S.No. & Topic & Constraints & $f(\%) *$ \\
\hline \multirow[t]{2}{*}{1.} & Climatic & Unexpected rain & $392(98.0)$ \\
\hline & & Outbreak of pests /diseases & $376(94.0)$ \\
\hline \multirow[t]{3}{*}{2.} & Seeds & High cost of seed & $334(83.5)$ \\
\hline & & Non-availability of seeds & $120(30.0)$ \\
\hline & & Adulterated seeds & $372(93.0)$ \\
\hline \multirow[t]{3}{*}{3.} & Fertilizer & Non-availability of fertilizer & $34(8.50)$ \\
\hline & & High cost of fertilizer & $396(99.0)$ \\
\hline & & Lack of knowledge about correct dose & $124(31.0)$ \\
\hline 4. & Irrigation & Water shortages in canal & $250(62.5)$ \\
\hline \multirow[t]{4}{*}{5.} & Plant protection & High cost of pesticide/chemicals & $396(99.0)$ \\
\hline & & Lack of knowledge about correct dose & $218(54.5)$ \\
\hline & & Adulteration & $328(82.0)$ \\
\hline & & Non availability & $152(38.0)$ \\
\hline \multirow[t]{2}{*}{6.} & Labourer & Shortage of labour & $222(55.5)$ \\
\hline & & High cost /wages & $310(77.5)$ \\
\hline \multirow[t]{3}{*}{7.} & Marketing & Heavy price fluctuation & $130(32.5)$ \\
\hline & & Very less Minimum Support Price (MSP) & $392(98.0)$ \\
\hline & & Low rate of return & $384(96.0)$ \\
\hline
\end{tabular}

*Multiple responses

Findings were in line with those of Mondal and Sinha (2015) that the problems faced by the cotton growers were endemic to pest and diseases, soil problems, effect of insecticides, drought and late heavy rainfall, labour problems, black marketing and private traders. 
Similar findings were reported by Maraddi et al., (2004), Reddy et al., (2010), Kumar et al., (2012) and Singh et al., (2013).

In conclusion, cotton is world's most important textile fibre and oil seed crop. For Indian farmer it is important cash crop, which is input and labour intensive. In the cotton crop farmers dependency increasers upon the seed companies due to the reason of growing $B t$ cotton. For every next crop farmers have to purchase seeds form the large companies, which ultimately reduces their profit margin. Our farmers are facing various constraints with regard to climatic conditions such as unexpected rain, outbreak of pest/diseases, seed related problems including adulterated seeds, high cost of seeds and non-availability of seeds. High cost of fertilizers, pesticides, and high cost of labour wages and less MSP and low rate of returns were also reported by the farmers. In order to sustain the optimum production and the productivity of soil, scientific and indigenous methods should be synergies together and policy intervention is utmost important for the farmers well being.

\section{References}

Aggarwal, P.K., Hebbar, K.B., Venugopalan, M.V., Rani, S., Bala, A., Biswal, A. and Wani S.P. 2008. Quantification of Yield Gap in Rain-fed Rice, Wheat, Cotton and Mustard in India. Global Theme on Agroecosystems. Report no.43 International Crops Research Institute for the Semi-Arid Tropics, India.

Anonymous, 2012. Statistical Abstract of Haryana, 2010-2011. Issued by Department of Economic and Statistical Analysis, Haryana Anonymous. 2013. Oversupply triggers price war among Bt hybrid cotton seed maker. http://www.indianbrokersassociation.com/ market/oversupply-triggers-price-waramong-bt-hybrid-cotton-seed-makers978.php

International Cotton Advisory Committee (ICAC). 2010. Outlook for World Cotton Supply and Use, Eurocotton, $49^{\text {th }}$ General Assembly, June 2010, Paris, France.

Majumdar, G. 2012. Mechanization of Cotton Production in India, CICR Technical Bulletin, Central Institute of Cotton Research, Nagpur, India.

Maraddi, G. N., Hirevenkanagoudar, L. V., Verma, N. S. and Halakeri, A. V. 2004. The constraints in the adoption of cotton production technologies in Malaprabha command area of Karnataka. International symposium on "Strategies for Sustainable Cotton Production" A Global Vision, Univ. Agric. Sci. Dharwad, Karnataka, India.

Mondal, D. and Sinha, S.K. 2015. Comparative analysis of the problems faced by the cotton growers in Gujarat. Journal of Cotton Research Development. 29 (1) 167-171

Reddy, K.G., Reddy, M.C., Reddy, D.V. and Kumar, S.R. 2010. Social Dynamics of cotton farmers in distress areas: A case of Andhra Pradesh. Journal of Cotton Research Development. 24 (2) 270-274

Shiv Kumar, C.L. 2007. An Economic Analysis of Production \& Marketing of Bt Cotton in Haryana and Karnataka. M.Sc. Thesis CCS Haryana Agricultural University, Hisar, Haryana

Singh, S., Kingra, H.S. and Singh, R. 2013. Input Utilization and constraints of cotton production in Punjab. Journal of Cotton Research Development. 27 (1) 144-148.

\section{How to cite this article:}

Reeta Devi Yadav and Rita Goel. 2019. Problems of Cotton Farmers in Haryana. Int.J.Curr.Microbiol.App.Sci. 8(03): 2139-2142. doi: https://doi.org/10.20546/ijcmas.2019.803.256 